\section{ST. ANDREWS INSTITUTE FOR CLINICAL RESEARCH.}

$T H E$ recent opening of an institute for clinical research in St. Andrews marks the beginning of a new era in the scientific development of the art of medicine. The enterprise has been initiated and brought to a happy stage of working order by Sir James Mackenzie, who is the director and controlling mind of its endeavours.

Briefly, the object of the institute is to investigate the early symptoms of disease before structural alterations in the body have had time to take place. Hitherto research has been mainly concerned with disease and its more advanced forms when structural and chemical changes can be detected by ordinary laboratory methods. But at the beginnings of disease symptoms of various kinds, often seemingly trivial, do occur. They become familiar to many general practitioners, though no serious attempt has been made to determine their cause and significance and to draw up a classification which will enable the medical man to appreciate their real meaning and thus put him into the position of being able to detect and arrest incipient disease.

For such purposes a small centre of population, where the same patients can be seen frequently and observed over long periods of time, is preferable to the larger centre with its rapidly moving population. St. Andrews should provide an ideal site, and has the further advantage of possessing a university and medical school with all that these imply. A suitable building has been secured overlooking the bay and in close proximity to the historic golf course.

The institute is affiliated to the University. Its staff consists of a director, a director of laboratory research, a trained biological chemist, a bacteriologist (to be appointed), a whole-time clinical assistant, and several part-time clinical assistants who are also practitioners in the town.

Three days a week patients are examined, and two days are given over to general discussions. The latter are wide in scope, and are freely opened to anyone who has anything to contribute. The trained logician and psychologist are especially welcome, and not infreauently join in the debate.

The institute is also educative, and aims at the training of the practitioner in the methods of research.

The institute has now been at work for some months, and is alreadv bearing fruit. It has promoted harmony and goodwill and a keen interest in their work among its members. It provides an excellent model for the development of other centres, and shows how a spirit of co-operation can be fostered among medical men which is of mutual benefit to themselves and to their patients. The scientific results will follow. P. T. HERring.

\section{FISHERY INVESTIGATIONS IN SOUTH AFRICA.}

THE Marine Biological Report of the Province of the Cape of Good Hope (No. 4) for the year ending June 30 , I9I8, has recently been received. The report is signed by Prof. J. D. F. Gilchrist, and although it appears that his department has been greatly restricted by lack of funds, it is clear that much useful work was done during the year under review. It is well known that a valuable industry in canning and exporting the local crawfish has been developed successfully at the Cape in recent years, and perhaps the most interesting feature of the report is an account of the habits of the different larval stages of this crustacean. The first larva of Jasus lalandii is NO. 2623 , VOL. IO4] small, somewhat opaque, and swims at the surface by its feather-like antennæ, the other appendages being folded close to the body and not used. This first stage, known as a "naupliosoma," continues for only a few hours, when it passes into the flattened "phyllosoma" stage. The larvæ in this stage are able to swim in a horizontal direction, but their natural habitat is still the surface waters. They were successfully reared, and after three or four days at most they passed into the third larval stage, in which they descend to the bottom and seek out the darkest corners. They then feed actively on the small animal and vegetable particles in the mud and sand, and are comparatively free from the attacks of their enemies. After undergoing a series of moults, which do not yet appear to have been followed in detail, the larva enters the "puerulus" stage, which has hitherto been found only close inshore.

Details of a number of experimental hauls for crawfish in different localities are given in the report, as well as an account of some marking experiments, which have thrown licht upon the migrations of this crustacean. A useful list is added of the different species of lobsters and crawfishes found in South African waters, with short, popular descriptions drawn $u_{p}$ by Mr. K. H. Barnard. Prof. H. B. Fantham contributes a short article on parasitic protozoa found in South African marine fishes, and the third and final list of Cape fishes, drawn up by the late Mr. W. Wardlaw Thompson, is included in the report. The strong recommendation of Prof. Gilchrist that the scientific fishery investigations, which have been suspended for a number of years, should now be resumed is one which will have the hearty support of all marine biologists, who know the valuable work which was formerly carried out under his direction.

\section{UNIVERSITY AND EDUCATIONAL INTELLIGENCE.}

Brrmingham.-At the meeting of the council held on January 29, the Pro-Vice-Chancellor in the chair, Mr. C. Grant Robertson received a cordial welcome as Principal of the University.

The thanlss of the council have been accorded to Mr. Arthur Serena for his generous offer to provide a sum of $5000 l$. towards the endowment of a department of Italian studies and a chair of Italian. Also to Mr. John Smith, of Edgbaston, for his offer to endow a prize for students in metallurgy in some educational establishment or establishments in Birmingham, to commemorate the contributions made by Prof. Turner to the science of metallurgy, to be known as "the Thomas Turner prize (or prizes) in metallurgy."

Lt.-Col. J. E. Dixon (Messrs. Rabone Bros.). Mr. Frank Gower (the Birmingham Aluminium Casting Co.), and Mr. Donald Hope (Messrs. Kynochs, Ltd.) have been appointed members of the Commerce Advisory Board.

Prof. John Robertson and Dr. C. J. Lewis have been appointed representatives of the University at the Congress of the Roval Sanitary Institute to be held in Birmingham in July next.

Mr. James Young has been appointed an assistant lecturer in the department of physics.

Cambridge.--The offer of a fund to endow a John Couch Adams astronomership in the University is announced. The offer was made by the late Mrs. Adams, widow of Prof. Adams, the discoverer of Neptune. The post, if established, is to be held by the director of the observatory unless he be at the same time a professor of the University, in which 